\title{
A TÁRGYSZAVAK FOGALMI ÉS MEGJELENÍTÉSI PROBLÉMÁI AZ EGYHÁZI GYUUJTEMÉNYEK KATALÓGUSAIBAN: ESETTANULMÁNY A DOMONKOS KÖNYVTÁR ÁLLOMÁNYÁNAK TARTALMI FELTÁRÁSA KAPCSÁN
}

\author{
NÉMETH Katalin \\ ELTE BTK KITI, egyetemi adjunktus
}

\begin{abstract}
ABSZTRAKT
A teológiai és vallástudományi szakirodalom fogalmi rendszere rendkívül összetett, felekezetenként, egyházanként heterogén. A szakkifejezések és a köznyelvben használt fogalmak gyakran keverednek, jelentésárnyalataik nem mindig következetesek, mint például a kolostor és a monostor esetében. A Magyarországon használt számos integrált könyvtári rendszer különböző lehetőségeket kínál a tárgyszavak leírására, átemelésére és visszakeresésére. A Magyar Evangélikus Bibliográfia számára készült tárgyszókatalógust részben adaptálni lehetne a katolikus könyvtárakban is, azonban például egy konkrét szerzetesi gyüjtemény esetében csak kismértékben használható, noha tartalmaz a katolikus egyházra jellemző kifejezéseket is. A sajátos fogalmi, nyelvhasználati és keresési szokások, melyek nem azonosak a világi érdeklődők keresési gyakorlatával sem, szintén nehezítik az egyházi könyvtárak állományának visszakereshetőségét. A MARC formátum biztosítja a deszkriptorok jelentéstartalmának pontosítását, szúkítését az almezőazonosítók révén, így egy-egy tárgyszóhoz több egyértelmúsítő kifejezést is lehet társítani, azonban a tárgyszavak megjelenítése - egy hívójel több almezővel, vagy a hívójel megismétlése - könyvtáranként eltér. Kérdés, hogy lehet-e, szükséges-e szabad tárgyszavakat használni, ami a szubjektivitás és következetlenség veszélyeit is hordozhatja?
\end{abstract}

A rendszerváltás utáni években a magyarországi egyházi könyvtárak a különböző nehézségek ellenére lehetőségeikhez mérten, olykor még azon felül is igyekeztek gyüjteményük és szolgáltatásaik tekintetében magas színvonalú munkát végezni. A modernizációs törekvéseknél több intézmény ugyan habozott az integrált könyvtári rendszer bevezetésénél, mivel a muzeális anyagok leírására nem volt megfelelő rendszer, azonban az ezredforduló után legnagyobb részük már Huntékát, Corvinát vagy Sziklát használt az állami könyvtárakhoz hasonlóan. ${ }^{1}$ Az ezredfordulón alapított Domonkos Rendtörténeti Gyújtemény ${ }^{2}$ könyvtára, melynek alapját a domonkos rend budapesti, soproni és vasvári rendházainak dokumentumai, valamint az Országos Széchényi Könyvtártól visszakapott kötetek jelentették, Vasváron az egykori domonkos kolostorban kapott elhelyezést. A könyvtári anyag formai és tartalmi feltárása megkezdődött, azonban a gyüjtemény tárgyszókatalógusának kialakítása több kérdést is felvetett, ezek közül szeretnék most néhány problémára rávilágítani. 


\section{NÉMETH KATALiN}

A felhasználók információkeresési szokásai az internetnek, a keresőmotoroknak köszönhetően jelentősen megváltoztak, már nem számítanak a könyvtárak katalógusai az első választásnak. Az adatbázisok, az indexelő szolgáltatások, melyek közvetlen hozzáférést biztosítanak a dokumentumokhoz, hozzájárulnak a könyvtári katalógusok használatának csökkenéséhez. ${ }^{3}$ A hazai könyvtárakban alkalmazott integrált könyvtári rendszerek különböző módon és mélységben teszik visszakereshetővé a dokumentumok tartalmát leíró tárgyszavakat, noha szükség volna a releváns információ megtalálásához a megfelelő kifejezésekre, mivel a publikációk címe, mely egyszerre igyekszik a figyelmet felkelteni és utalni a tartalomra, mégsem képes minden esetben lefedni a dokumentum teljes jelentését. Gyakran maguk a felhasználók sem ismerik a keresett dokumentum szerzőjét vagy címét, illetve sokszor előzetesen szeretnének tájékozódni egy-egy témával kapcsolatban, ezért is nélkülözhetetlen a megfelelő tárgyszórendszer kialakítása. A formai és tartalmi feltárás során szerepet kell, hogy kapjanak a tárgyi melléktételek, mint például a személyi és földrajzi tárgyi melléktételek. A MARC (Machine Readable Cataloging) formátum révén az egyszerűbb, menümódos felületekhez képest árnyaltabb, a hierarchiát jobban tükröző tárgyszavakkal jellemezhetjük köteteink tartalmát.

A Domonkos Rendtörténeti Gyűjtemény a Dr. Bendefy László Városi Könyvtárral együtt vásárolta meg 2010-ben a Szikla integrált könyvtári rendszert, melyben a két könyvtár anyaga együtt vált elérhetővé, jelenleg a leltári szám utal a kötetek tulajdonosára. A domonkos anyag katalogizálása a közös felület ellenére független a városi könyvtár dokumentumainak feldolgozásától, így nincsenek egymásra közvetlen hatással. A domonkos könyvtár nem rendelkezik kötött tárgyszókatalógussal. Ennek elkészítéséhez szükséges a domonkos renddel való további egyeztetés, mivel ugyan kiindulópontot jelenthetnek más szerzetesrendek tárgyszavai, azonban vannak olyan témakörök, szakterületek, melyek elsősorban a domonkosokra jellemzők, így azokat a megfelelő mélységű, pontos jelentéstartalmú, speciális tárgyszavakkal kell leírni. A formai és tartalmi feltárás megkezdésekor nem volt egységes és következetes a tárgyszavak használata. Például az Árpád-házi Szent Margit életéről, szentté avatásáról szóló kötetek tárgyszavai között leggyakrabban a következők találhatóak: szent (domonkos), életrajz (domonkos szent), életrajz (domonkos nővér). A felsoroltakat kiegészíthette volna a szentté avatás, valamint nem szerencsés a zárójeles megoldás sem, azonban következetesen minden esetben megjelent Margit nevének egységesített besorolási adata, mint tárgyi melléktétel.

\section{Három kötet sok megoldással}

A Magyar Evangélikus Bibliográfia számára készített tárgyszókatalógus, vagy más szerzetesrendek könyvtárainak katalógusai mintát adhatnak a domonkos tárgyszójegyzék részére. Nézzünk azonban néhány példát más könyvtárak katalógusaiból, melyek jól szemléltetik a tartalmi feltárás következetlenségeit! Emellett mindenképpen meg kell jegyezni, hogy a szakozás minőségének megítélése rendkívül összetett kérdés, hiszen függ például a gyűjtemény nagyságától, az állomány összetételétől, a feldolgozási folyamatok szabályozottságától vagy a könyvtárosok számától. 
A TÁRGYSZAVAK FOGALMI ÉS MEGJELENÍTÉSI PROBLÉMÁI AZ EGYHÁZI GYÜJTEMÉNYEK KATALÓGUSAIBAN: ESETTANULMÁNY...

Három dokumentumot választottam, mely a Domonkos Rendtörténeti Gyújtemény mellett több könyvtár állományában is megtalálható. A könyvtárak katalógusait elsősorban az Unitas, az Egyházi Könyvtárak Közös Katalógusán ${ }^{4}$ keresztül vizsgáltam, valamint visszakerestem a köteteket az Országos Széchényi Könyvtár (OSZK) és az Eötvös Loránd Tudományegyetem Egyetemi Könyvtárában ${ }^{5}$ is, mely utóbbi teológiai gyújtőkörrel is bír. A három választott kötet a következő:

- Bóle Kornél: Boldog Margit legendája. Budapest: Királyi Magyar Egyetem, [1938]. 218 p.

- Bőle Kornél: Árpádházi Boldog Margit szenttéavatási ügye és a legősibb latin Margit-legenda. Budapest: Stephaneum Ny., 1937. 43 p.

- Bőle Kornél: A háromszázéves szombathelyi zárdánk. Budapest: Credo, 1938. $116 \mathrm{p}$.

Bőle Kornél (1887-1961), a Credo folyóirat alapítója az első két kötetben Szent Margit életét mutatja be, a harmadikban pedig a szombathelyi zárda történetét. A tanulmányban nem szerepel a vizsgált könyvtárak neve, azonban az alábbi néhány példa jelzésértékű az egyes könyvtári katalógusok esetleges ellenőrzéséhez, korrekciójához. A táblázatokban nem egyezik meg a könyvtárak száma, mivel értelemszerűen csak azok a könyvtárak kerültek be, ahol az adott kötet adatai elérhetők voltak.

A Boldog Margit legendájához az 1. táblázatban olvasható tárgyszavakat találjuk nyolc könyvtár katalógusában, különböző írásmóddal és mélységben. A bagiológia és a sæ̣entek élete tárgyszavak tükrözik leginkább a dokumentum tartalmát, de csak az utóbbi mellett szerepel tárgyi melléktételként Szent Margit neve.

1. táblázat: A Boldog Margit legendája tárgyszavai

\begin{tabular}{|l|l|}
\hline & \multicolumn{1}{|c|}{ Tárgyszavak } \\
\hline 1. & - \\
\hline 2. & Hagiológia \\
\hline 3. & Margit legenda, lelki irodalom, szentek élete (magyar) \\
\hline 4. & - \\
\hline 5. & szentek élete \\
\hline 6. & - \\
\hline 7. & Spirituális \\
\hline 8. & Szentek - Magyarország \\
\hline
\end{tabular}

Négy könyvtár veszi fel Margit nevét tárgyi melléktételként, ahogy azt a 2. táblázat mutatja. Ennek a harmadik oszlopában MARC formátumban olvasható az egységesített besorolási adat, kettő katalógusban azonban a 600-as hívójel helyett 700-as hívójellel. 
2. táblázat: A Boldog Margit legendája tárgyi melléktételei

\begin{tabular}{|l|l|l|}
\hline & \multicolumn{1}{|c|}{ Tárgyi melléktétel } & \multicolumn{1}{c|}{ Tárgyi melléktétel MARC } \\
\hline 1. & $\begin{array}{l}\text { Margit (Szent) , Árpád-házi (1242- } \\
1270)\end{array}$ & $\begin{array}{l}60014 \text { | a Margit |c Szent |c Árpád-házi |d } \\
1242-1270\end{array}$ \\
\hline 2. & - & 7000 \$a Margit \$c Árpádházi \$c Szent \\
\hline 3. & Margit, Szent, Árpád-házi OP & - \\
\hline 5. & Margit, Árpád-házi, Szent (1242-1271) & $\begin{array}{l}60004 \text { \$a Margit, \$c Árpád-házi, \$c Szent, \$d } \\
(1242-1271)\end{array}$ \\
\hline 8. & Margit Szent, Árpád-házi (1242-1271) & $\begin{array}{l}700 \text { 0 \$a Margit, \$c Szent, \$c Árpád-házi, \$d } \\
(1242-1271)\end{array}$ \\
\hline
\end{tabular}

Az Arpádházi Boldog Margit szenttéavatási ügye és a legösibb latin Margit-legenda című rövid kötet több könyvtár esetében is több tárgyszót, tárgyszóláncot kapott, ahogy a 3. táblázatban látható. Az első könyvtár kivételével mindenütt szerepel legalább egy olyan kifejezés, ami utal arra, hogy a dokumentum egy szent életéról vagy szenttéavatási eljárásáról szól.

3. táblázat: A szenttéavatás kötet tárgyszavai

\begin{tabular}{|l|l|}
\hline & \multicolumn{1}{|c|}{ Tárgyszavak } \\
\hline 1. & egyháztörténet--magyar--13. sz. \\
\hline 2. & domonkos szerzó, szenttéavatás \\
\hline 3. & életrajz (szent - magyar), legenda, szenttéavatás \\
\hline 4. & - \\
\hline \multirow{2}{*}{5.} & legenda Szent Margit \\
\cline { 2 - 2 } & szenttéavatás \\
\hline \multirow{2}{*}{6.} & Szentek \\
\cline { 2 - 2 } & Szentek élete \\
\cline { 2 - 2 } & Magyar egyháztörténet \\
\hline \multirow{2}{*}{7.} & Szentek élete \\
\cline { 2 - 2 } & Margit, Szent, Árpádházi (1242-1271) \\
\hline 8. & szentek élete - magyar \\
\hline 9. & - \\
\hline
\end{tabular}

Kilenc könyvtárból ennél a kötetnél nyolcnál találunk tárgyi melléktételt, ott marad ki, ahol tárgyszóként lett feldolgozva. A tárgyi melléktételekkel kapcsolatban meg kell jegyezni, ahogy a 2. és 4. táblázatból is látható, hogy Margit nevének egységesített besorolási adata nem minden esetben pontos, a személynevek egységesítése nem megoldott. A katalógusokban a személynév az egyik leggyakoribb besorolási adat, valamint keresési szempont, amely segíti az olvasót, hogy eljusson az általa keresett dokumentumhoz. Az eredményes kereséshez elengedhetetlen, hogy a személynév mindig ugyanabban az 
A TÁRGYSZAVAK FOGALMI ÉS MEGJELENÍTÉSI PROBLÉMÁI AZ EGYHÁZI GYÜJTEMÉNYEK KATALÓGUSAIBAN: ESETTANULMÁNY...

egységes, szabványos alakban kerüljön a katalógusba, legyen az a dokumentum szerzője, vagy éppen, mint Szent Margit esetében is, tárgyi melléktétel. ${ }^{6}$

4. táblázat: A szenttéavatás kötet tárgyi melléktételei

\begin{tabular}{|l|l|l|}
\hline & \multicolumn{1}{|c|}{ Tárgyi melléktétel } & \multicolumn{1}{c|}{ Tárgyi melléktétel MARC } \\
\hline 1. & $\begin{array}{l}\text { Margit, (Szent,) Árpád-házi (1242- } \\
\text { 1270) }\end{array}$ & $\begin{array}{l}600 \text { 04 | a Margit, |c Szent, |c Árpád-házi } \\
\mid \mathrm{d} 1242-1270\end{array}$ \\
\hline 2. & Margit, Szent, Árpád-házi (1242-1270) & - \\
\hline 3. & Margit, Szent, Árpádházi & - \\
\hline 4. & Margit, Szent, Árpád-házi (1242-1270) & $\begin{array}{l}600 \text { 04 a Margit g Szent, Árpád-házi d } \\
1242-1270\end{array}$ \\
\hline 5. & Margit, Árpád-házi, Szent (1242-1271) & $\begin{array}{l}600 \text { 04 \$a Margit, \$c Árpád-házi, \$c Szent } \\
\text { \$d (1242-1271) }\end{array}$ \\
\hline 6. & Margit, Szent, Árpádházi & 6001 \$a Margit, Szent, Árpádházi \\
\hline 7. & - & - \\
\hline 8. & Margit, Szent, Árpád-házi (1242-1271) & $\begin{array}{l}\text { 600 04 \$a Margit, \$c Szent, \$c Árpád-házi } \\
\text { \$d (1242-1271) }\end{array}$ \\
\hline 9. & Margit, Szent, Árpád-házi (1242-1271) & $\begin{array}{l}600 \text { a Margit, \$c Szent, \$c Árpád-házi \$d } \\
(1242-1271)\end{array}$ \\
\hline
\end{tabular}

A harmadik választott kötet, $A$ báromszázéves szombathelyi zárdánk egy másik problémára is rávilágít. A kötethez rendelt tárgyszavakat az 5. táblázat sorolja fel, melyből kitűnik, hogy ez az első vizsgált dokumentum, melynél minden könyvtár katalógusában található utalás a domonkos rendre. A táblázat negyedik könyvtára a domonkosokat négyszer említi, bár az utolsó (a rend latin neve) tárgyi melléktételnek kívánkozna, az első három különválasztja a földrajzi egységet és a tematikai szempontot, amit össze is lehetett volna vonni.

5. táblázat: A háromszázéves szombathelyi zárda kötet tárgyszavai

\begin{tabular}{|l|l|}
\hline & \multicolumn{1}{|c|}{ Tárgyszavak } \\
\hline 1. & domonkos rend -- zárda - Szombathely \\
\hline \multirow{3}{*}{2.} & domonkos közremúködő \\
\cline { 2 - 2 } & domonkos rendtörténet \\
\cline { 2 - 2 } & domonkos kolostor (Szombathely) \\
\hline 3. & - \\
\hline \multirow{4}{*}{4.} & domonkos rend - Magyarország \\
\cline { 2 - 2 } & domonkos rend - történet \\
\cline { 2 - 2 } & domonkosok - Szombathely \\
\cline { 2 - 2 } & Ordo Fratrum Praedicatorum, OP \\
\hline \multirow{2}{*}{5.} & Katolikus egyház, Magyarország, regionális, története \\
\cline { 2 - 2 } & Domonkos-rend, Magyarország, regionális \\
\hline
\end{tabular}




\section{NÉMETH KATALiN}

A könyvtárak közül kettő vette fel Szombathely nevét mint tárgyi melléktételt, bár nem feltétlenül szükséges, hiszen a dokumentum nem a város történetére fókuszál. Mi a probléma mégis a választott tárgyszavakkal?

\section{Kolostorok, monostorok, szinonimák?}

Szombathelyen két domonkos zárda volt, és most legyünk óvatosak a zárda kifejezéssel. Az elsőt 1638-ban ${ }^{7}$ alapította Draskovich György győri püspök, a második 1905-ben létesült, amikor az Árpád-házi Szent Margitról Nevezett Szent Domonkos Rendi Nővérek Apostoli Kongregációja a kőszegi, vasvári és hódmezővásárhelyi rendház után Szombathelyen is közösséget alakított. Ebből nyilvánvaló, hogy az említett kötet címe csak az 1638-as alapításra utalhat, tehát a férfi rendházra.

A zárda szavunk a felhasználóban és a könyvtárosban is sokszor a női kolostorok képét idézi fel, noha az etimológiája a claustrum szóra ${ }^{8}$ vezethető vissza, és egyértelműen nem különíthető el a kolostor szavunktól, mely egyaránt lehet női és férfi szerzetesközösség lakhelye, tehát értelmezhetők egymás szinonimáiként. Egy fogalmat célszerű csak egy kifejezésnek megfeleltetni, tehát a szinonimák párhuzamos használatát mellőzni kellene, azonban az ilyen döntéseket „lásd” utalóval is meg kellene erősíteni. ${ }^{9}$ A könyvtárak a zárda szót nagyon ritkán használják tárgyszóként, leggyakrabban akkor, ha a címben is olvasható, viszont az, hogy a címben szerepel, nem jelenti automatikusan azt, hogy tárgyszóként is szerepelni fog, még akkor sem, ha indokolt lenne a használata. Álljunk is meg egy pillanatra a szerzetes közösségekkel kapcsolatos fogalmaknál, mint kolostor, monostor, klastrom, rendház, konvent, apátság, zárda!

A többnyire szinonimaként használt két fogalom, a kolostor és a monostor másmás funkciót takar. A görög eredetủ monostor szó jelöli a monasztikus rendek templommal egybeépített épületegyüttesét, mely a rend-tagok valamennyi életfunkcióját (szállás, étkezés, ima, önellátó ipar, gazdálkodás) hivatott kiszolgálni. A latin eredetủ kolostor (claustrum monasterii), mely a klastrom szavunk későbbi megfelelője, a rendház laikusok elől elzárt részét, a szerzetesi szállásépületet jelölte, melyhez templom is csatlakozhatott. ${ }^{10}$

Ha megnézzük a katalógusokat, a kolostor-monostor-klastrom hármasból, vagy akár a zárdával kiegészítve, a legtöbbet használt kifejezés a kolostor, mind a dokumentumok címében, mind a tárgyszavak szintjén. A 6. táblázat az Unitas katalógusának tárgyszavait és címkulcsszavait mutatja további, a szerzetesközösségekkel kapcsolatban használt fogalmakkal. Az összehasonlításhoz mellette jelennek meg a táblázatban a Magyar Országos Közös Katalógus (MOKKA) tárgy- és címkulcsszavai. A klastromot tárgyszóként szinte sehol nem látjuk, valószínúleg nem is nagyon keresnék az olvasók, azonban azoknál a dokumentumoknál, ahol a címben előfordul, és a dokumentum tartalma is megkívánná, ott sem találjuk, de gyakran a szinonimáját sem, a kolostort. 
A TÁRGYSZAVAK FOGALMI ÉS MEGJELENÍTÉSI PROBLÉMÁI AZ EGYHÁZI GYÜJTEMÉNYEK KATALÓGUSAIBAN: ESETTANULMÁNY...

6. tábláąat: A kolostor, mint tárgy-és kulcsszó megjelenése a katalógusokban

\begin{tabular}{|l|c|c|c|c|}
\hline & \multicolumn{2}{|c|}{ Unitas } & \multicolumn{2}{c|}{ MOKKA } \\
\hline Fogalom & Tárgyszó & Címkulcsszó & Tárgyszó & Címkulcsszó \\
\hline kolostor & 141 & 358 & 652 & 739 \\
\hline kolostorok & 158 & 149 & 235 & 196 \\
\hline kolostori & 15 & 59 & 598 & 125 \\
\hline monostor & 41 & 160 & 142 & 206 \\
\hline zárda & 3 & 48 & 16 & 94 \\
\hline klastrom & 0 & 8 & 1 & 53 \\
\hline apátság & 502 & 475 & 615 & 592 \\
\hline konvent & 33 & 182 & 21 & 262 \\
\hline rendház & 43 & 119 & 114 & 170 \\
\hline
\end{tabular}

Tovább árnyalja a képet, hogy például a kolostor nemcsak egyes számban, hanem többes számban is gyakran előfordul, ez pedig problémát okoz azoknál az integrált könyvtári rendszereknél, amelyek nem csonkolnak automatikusan, nem csak a szó eleji illeszkedést veszik figyelembe. A szavakat célszerű alanyesetben és egyes számban használni, azonban indokolt esetben a többes szám is elfogadható lehet. A MOKKA egyetlen klastrom tárgyszava a Klastrom Szálloda jelene és múltja címú szakdolgozat tartalmát leíró kifejezések között szerepel, de itt sem önállóan, hanem az intézmény nevének részeként tárgyi melléktétel formájában. Az Unitas közös katalógus esetében a klastrom keresőkifejezés, mint tárgyszó, egyetlen találatot sem eredményez, azaz nem csak nem szerepel a katalógusban, de nem is irányítja tovább az olvasót utalóval.

Előfordul, hogy jelzôvé válik a főnév, ilyenkor érdemes végiggondolni, hogy indokolt-e a jelzős szerkezet, vagy több tárgyszóval körül lehet-e írni, így kikerülve a jelzős szerkezetek használatát. Szükséges lehet a jelzők alkalmazása például az egyes vallásoknál és az egyházakat általánosságban tárgyaló dokumentumoknál, de az egyes szerzetesrendek tárgyszavazása is jelzős szerkezettel kifejezve egyenes szórendben a legegyszerúbb. Ebben a legtöbb egyházi könyvtár katalógusa is következetes, amíg csak magáról a rendről készül a tárgyszó. Itt nem szabad elfelejteni, hogy amennyiben a tartalom megköveteli, tárgyi melléktétel is szükséges a szerzetesrend nevének egységesített besorolási adatával, illetve ehhez megfelelő utalók.

A MARC-ot nem használó integrált könyvtári rendszerekben, melyek kevésbé képesek kifejezni a hierarchiát és a struktúrát, vagy egyszerűen nincs a könyvtárnak kapacitása a megfelelő mélységű tárgyszavazásra, találhatunk olyan tárgyszavakat, mint domonkos rendtörténet, rendtörténet (domonkos), domonkos szent, szent (domonkos), életrajz (domonkos szent), életrajz (domonkos nővér) stb. És vissza is jutottunk a Szent Margittal kapcsolatos dokumentumok tárgyszavazásához. Mi lenne az ideális tárgyszó? Tárgyszólánc? Természetesen kérdés, hogy kötött, előre meghatározott tárgyszójegyzékkel dolgozunk, vagy meghagyjuk a feldolgozó könyvtáros szabadságát.

A fenti táblázatok tapasztalatai alapján látható, hogy rendkívül heterogén megoldást alkalmaznak a könyvtárak. A már említett Magyar Evangélikus Bibliográfia valóban 


\section{NÉMETH KATALiN}

csak kiindulópont lehet a domonkos tárgyszókatalógus elkészitéséhez, mivel számos olyan fogalom hiányzik, ami például a domonkos irodalomra kiemelten jellemző, mint a rózsafüzér. Ez egy újabb fogalom, ami tárgyszavak szintjén is pontosításra szorul: a rózsafüzér, más néven szentolvasó (ebben a formájában a katalógusok nem is ismerik), mint ima és mint eszköz, mint a rózsafüzért elemző teológiai irodalom vagy mint a rózsafüzér imádságok kötete is megjelenhet. Ezért is kell mindig az adott tudományterület szakkifejezéseit használni, valamint szerencsés, ha a kötött tárgyszókatalógus fogalmait a szakterületen jártas személy készíti, de éppen úgy kedvező, ha a feldolgozó könyvtáros is rendelkezik azzal a szakterületi jártassággal, amely lehetővé teszi, hogy pontosan felismerje a feltárandó dokumentum tartalmát.

Feltehetünk egy másik, egyre aktuálisabb kérdést is a tárgyszavak létrehozásával kapcsolatban. Használhatunk-e tageket, adhatnak-e a felhasználók tárgyszavakat az általuk ismert, olvasott dokumentumoknak? Egyes könyvtártípusok már nyitnak a felhasználók felé, azonban mindenképpen kell olyan személy, szakember, aki ellenőrzi, javítja az olvasók tárgyszó javaslatait. ${ }^{11}$ Talán a fogalmi rendszere, sokszínűsége miatt amúgy is heterogén teológiai irodalom feltárásának első lépése a tudományterület fogalmi rendszerének leképezése kell, hogy legyen a tárgyszavak szintjén.

Tanulmányommal azt kívántam felvillantani, hogy egy viszonylag homogén gyűjtemény esetében is milyen nehézségekbe ütközik a precíz, a felhasználói igényeket kielégítő, a dokumentumok visszakereshetőségét, azonosíthatóságát biztosító tárgyszórendszer kialakítása, a tárgyszavazás megvalósítása. Megoldásként egy, az egyházi könyvtárak és a vallástudományi gyűjtőkörrel rendelkező könyvtárak összefogásával kialakított tárgyszórendszer létrehozása javasolható, mely a fogalmak tisztázása után, a leggyakrabban használt kereső kifejezések mentén készül.

\section{Irodalom}

${ }^{1}$ ÁSVÁNYI Ilona: Töprengések az egyházi könyvtárak sorsának változásáról. = Könyv, Könyvtár, Könyvtáros, 20. évf. 6. sz. 2011. 3-14. p.

${ }^{2}$ NÉMETH Katalin: A vasvári Domonkos Rendtörténeti Gyüjtemény. = Könyvtári Figyelő, 57. évf. 4. sz. 2011. 774-778. p.

${ }^{3}$ OWEN, Will - MICHALAK, Sarah C.: Engine of Innovation: Building the High Performance Catalog. = Information Technology and Libraries, Vol. 34. No. 2. 2015. 5-18. p.

${ }^{4}$ Unitas. Az Egyházi Könyvtárak Közös Katalógusa és Információs Portálja. Forrás: http://[-] www.unitas.hu [2016. január 10.]

${ }^{5}$ ELTE Egyetemi Könyvtári Szolgálat katalógusa. Forrás: http://aleph.elte.hu [2016. január 10.]

${ }^{6}$ KÖNTÖS Nelli: Szerzők nyomában: a könyvtári szabványok szerepe az intézményi publikációs adattárak névkezelési stratégiájában. = Könyvtári Figyelő, 58. évf. 2. sz. 2012. 255-279. p.

${ }^{7}$ Egyházi beszéd mellyet Sz. Mártonban a’ sz. Domonkos rend' ottani behozatásának két századik évfordultán, 1838ki Aprilis hó’ 15kén, mondott Szenczy Ferencz... Kőszeg, Reichard Károly Nyomda, 1838. 22 p. 
${ }^{8}$ BÁRCZI Géza: Magyar szófejtő szótár. Budapest, Trezor Kiadó, 1991. 168. p.; A magyar nyelv történeti-etimológiai szótára: Ö-Zs. Szerk. Benkő Loránd. Budapest, Akadémiai Kiadó, 1976. 1187. p.

9 ASZALÓS Károly [et al.]: ELTE EKSZ a tartalmi feltárás (tárgyszavazás) szabályzata. Forrás: https://edit.elte.hu/xmlui/bitstream/handle/10831/18384/ELTE\%20Tartalmi\%20[-] Szab\%C3\%A1lyzat.pdf?sequence=1\&isAllowed=y [2016. január 10.]

${ }^{10}$ GECSE Gusztáv: Vallástörténeti kislexikon. Budapest, Kossuth, 1977. 198. p.; A magyar nyelv történeti-etimológiai szótára: H-Ó. Szerk. Benkő Loránd. Budapest, Akadémiai Kiadó, 1970. 952. p.

${ }^{11}$ ROLLA, Peter J.: User Tags versus Subject Headings: Can User-Supplied Data Improve Subject Access to Library Collections? = Library Resources \& Technical Services, Vol. 53. No. 3. 2009. 174-184. p.

Németh Katalin egyetemi adjunktus, az ELTE BTK Könyvtár- és Információtudományi Intézetének oktatásfelelőse, a Magyar Könyvtárosok Egyesületének tagja. Kutatási területe: domonkos könyvkultúra, könyvtári menedzsment, ügyfélkapcsolat-menedzsment. 